\title{
EFFECTIVENESS OF COMPOST AND MICROBIAL-ENRICHED COMPOST TO SUPPRESS POWDERY MILDEW AND EARLY BLIGHT DISEASES IN TOMATO
}

\author{
N. Istifadah ${ }^{*}$, A. R. Firman and M. F. Desiana \\ Department of Plant Pests and Diseases, Faculty of Agriculture, Universitas Padjadjaran \\ Jl. Raya Bandung - Sumedang Km. 21 Jatinangor 45363, West Java, Indonesia. \\ *Corresponding author's email: n.istifadah@unpad.ac.id
}

\begin{abstract}
Compost and its water extract have the potential to suppress plant diseases. This study aimed to compare the effectiveness of compost and compost enriched with antagonistic fungi (compost plus) in controlling powdery mildew and early blight diseases in tomatoes, in the greenhouse and in the field. Compost and compost plus were applied as water extract sprayed onto the leaves every three or seven days, with or without combination with its applications in the planting media. The results showed that the microbial-enriched compost resulted in better disease suppression than the non-enriched compost. The application of compost or compost plus to the growth medium enhanced the effects of the water extract sprayed on the leaves. The compost plus incorporated in the nursery medium and planting holes, as well as spraying the water extract on the leaves every three or seven days, suppressed powdery mildew and early blight diseases by $41-49 \%$. This study revealed that even though the enriched compost was intended for controlling soilborne diseases, their water extract can also be used for controlling airborne diseases.
\end{abstract}

Key words: antagonistic fungi, field-grown tomato, compost plus, water extract. https://doi.org/10.36899/JAPS.2020.2.0031

Published online March 02, 2020

\section{INTRODUCTION}

Tomatoes can be cultivated in greenhouses or in plastic houses, as well as in the fields. One of the limiting factors in greenhouse tomato cultivation is powdery mildew disease caused by Oidium neolycopersici (Jacob et al., 2008; Cerkauskas and Brown, 2015). The pathogen infects all aerial parts of tomato plants, excluding the fruits. Severe infections lead to premature senescence of the leaves and reduction in the fruit size (Jacob et al., 2008). In field-grown tomatoes, one of destructive diseases is early blight disease (Alternaria solani). The pathogen infects all aerial parts of the plants, leading to leaf defoliation and significant yield loss (Gulzar et al., 2018).

The most common control measure of the diseases is the use of pesticides. However, the intensive use of pesticides for long periods can lead to many negative impacts, such as the development of resistant pathogens, environmental pollution and accumulation of pesticide residues on the agricultural products (Mahmood et al., 2016). The increase in environmental awareness and the demands of pesticide-free products have encouraged the development of environmentally friendly disease control measures, including the use of organic matters, such as compost.

The ability of compost to control soil-borne diseases has been reviewed (Mehta et al., 2014). In addition to its effects on soilborne diseases, compost can also induce plant resistance to air-borne diseases (Yogev et al., 2010; Segarra et al., 2013). For controlling airborne diseases, compost can be applied in the form of water extract or compost tea, applied as foliar sprays. The efficacies of compost tea to suppress various air-borne diseases have been reported (Marín et al., 2013; St. Martin, 2014).

The suppressive effects of compost tea on plant diseases could be due to several mechanisms. Generally, the suppressive effects of compost tea are associated with microorganisms, as the suppressive effects were usually decreased or eliminated by sterilisation (Marín et al., 2013; St. Martin, 2014). Microorganisms in the compost tea can also induce the plants resistance to the pathogens (Sang et al., 2010; Sang and Kim, 2011). In some cases, the disease control by compost tea was also due to heatstable chemical compounds (Sang et al., 2010; Marín et al., 2013).

The disease suppressive effects of compost, however, are usually inconsistent. The addition of antagonistic microbes to compost can improve the level and consistency of the suppressive effects (Mehta et al., 2014). For example, the enrichment of compost with Trichoderma harzianum (Pugliese et al., 2011; Ros et al., 2017) or Trichoderma asperellum (Ros et al., 2017) have been reported to enhance the disease suppressive effects.

We have developed compost enriched with several antagonistic fungi (Trichoderma harzianum, Papulaspora sp. and Paecilomyces fumosoroseus), called 'compost plus'. The incorporation of compost plus into the nursery medium and planting holes suppressed 
Fusarium wilt disease in tomatoes (Istifadah et al., 2008). Even though it was intended to control soilborne diseases, the water extract of compost plus applied as foliar sprays was expected to suppress airborne diseases. A combination of compost or compost plus applications, which are incorporated into the soil and topical sprays of their water extract, is expected to provide comprehensive control.

The objectives of this study were first, to compare the abilities of the water extract of compost and compost plus to suppress powdery mildew in the greenhouse tomatoes, and early blight disease in the field-grown tomatoes; second, to determine if a combination of compost or compost plus applications (such as soil amendment and foliar sprays of the water extract) enhanced their efficacy to control the airborne diseases; finally, to determine the involvement of antagonistic microorganisms in the disease suppression.

\section{MATERIALS AND METHODS}

Water extracts of compost and compost plus: The compost used in this study was made from domestic waste mixed with cow manure (produced by the Faculty of Animal Husbandry, Universitas Padjadjaran, Bandung, Indonesia). For compost plus, the compost was combined with antagonistic fungi: T. harzianum, Papulaspora sp. and $P$. fumosoroseus (prepared based on the method developed by Istifadah et al., 2008). The water extract of compost or compost plus was prepared by mixing the material with water $(1: 4, \mathrm{v}: \mathrm{v})$ and incubated in a close-lid container for seven days. The water extract was strained and added with Tween $80\left(0.5 \mathrm{~mL} \mathrm{~L}^{-1}\right)$.

Greenhouse experiment: The experiment examining efficacies of compost and compost plus in controlling powdery mildew disease were conducted at the greenhouse of Agriculture Faculty, Universitas Padjadjaran, Indonesia. It was arranged in a randomised complete block design with ten treatments and three replications. The treatments encompassed the application of compost or compost plus in planting media combined with foliar sprays of its water extract every three or seven days; foliar sprays of compost or compost plus water extract every three or seven days; fungicide (propineb) sprays every seven days; and the check (untreated plants).

The application of compost or compost plus in the growth medium was conducted in the nursery by mixing the materials with pasteurised soil $(1: 2, \mathrm{v}: \mathrm{v})$, and at the time of transplanting by applying $40 \mathrm{~g}$ of compost or compost plus in the planting hole (Istifadah et al., 2008). The growth medium used in the polybag was a mixture of pasteurised soil and goat manure $(3: 1, \mathrm{v}: \mathrm{v})$.

Considering that $O$. neolycopersici is an obligate parasite, the inoculum used were powdery mildew infected leaf pieces $\left(1 \mathrm{~cm}^{2}\right)$ of tomatoes. Sticky tape was placed on the back of the infected leaf then inverted onto the adaxial surface of the tomato leaf, and then fastened with plastic wrap. The inoculation was conducted on the tip of each tomato compound leaf. The pathogen inoculation was conducted one day after the foliar spray of the water extract from compost or compost plus. The infected leaf pieces were removed three days after inoculation. The water extract of compost or compost plus was sprayed onto the tomato leaves regularly (depending on the treatment), and this was started seven days after the pathogen inoculation.

The variables observed were the appearance of powdery mildew symptoms for the first time (considered as the incubation period), the disease intensity and plant height, as well as shoots fresh weight (measured six weeks after the pathogen inoculation). The disease intensity was observed every week for six weeks. The disease intensity was calculated by the following equation: $\mathrm{I}=\left[\left(\sum\left(\mathrm{n}^{*} \mathrm{v}\right)\right) /\left(\mathrm{N}^{*} \mathrm{~V}\right)\right]^{*} 100 \%$, in which $\mathrm{I}(\%)$ : disease intensity; $\mathrm{v}$ : disease index; $\mathrm{n}$ : the number of leaves with the same disease index; $\mathrm{N}$ : total numbers of leaves observed and V: the highest disease index used.

Disease index used was modified from Horsfall Barret (Campbell and Madden, 1990), in which $0=$ no lesion; 1 = percentage of infected leaves $0<\mathrm{x} \leq 12 \% ; 2=$ percentage of infected leaves $12 \%<\mathrm{x} \leq 25 \% ; 3=$ percentage of infected leaves $25 \%<\mathrm{x} \leq 50 \% ; 4=$ percentage of infected leaves $50 \%<\mathrm{x} \leq 75 \%$; $5=$ percentage of infected leaves $75 \%<\mathrm{x} \leq 100 \%$. The development of disease during the observation period was quantified as Area under Disease Progress Curve (AUDPC) (Campbell and Madden, 1990).

Field experiment: The efficacy of the water extract of compost and compost plus on early blight disease was examined in the field experiment, conducted in Lembang, West Bandung, West Java, Indonesia. The experiment was arranged in randomised complete block design with ten treatments and three replications. Each replication consisted of three rows with 24 tomato plants per row. The treatments were the same with those in the greenhouse experiment, except that the fungicide used had mankozeb active ingredient. The cultivation technique (plant spacing and fertilisers) used was the same as the one farmer's commonly practice. The water extract of compost or compost plus was applied regularly (depending on the treatments) starting at three weeks after transplanting, when the early blight disease symptoms had already occurred in every treatment.

Disease intensity was observed every week. The sample plants for each replication were ten plants in the middle row. The weight of healthy fruits per plant was gathered from three times of harvest.

In vitro assessment: The objective of the test was to examine the factors involved in the suppressive effects of the compost and compost plus. To find out if the toxic 
compound was involved in the inhibition, the water extract was sterilised by filtration (using a $0.2 \mu \mathrm{m}$ pore microfilter), while to test the involvement of microorganisms in the extract, the non-sterile water extract was also examined. The experiment was arranged in completely randomized design with five treatments and four replications. The treatments consisted of water extract of compost and compost plus, which were sterile or non-sterile, and the check (untreated medium). The sterile or non-sterile water extract $(1 \mathrm{~mL})$ was placed in the petri dish before pouring $9 \mathrm{~mL}$ of potato dextrose agar (PDA) into the petri dish. A plug of $A$. solani culture (diameter $0.8 \mathrm{~cm}$ ) was inoculated in the treated media and non-treated medium (the check). The diameter of the pathogen colony was observed every day for up to seven days incubation.

The population of microbes in the water extract of the compost and compost plus was examined using serial dilution and total plate count (TPC) methods with PDA and nutrient agar as media. The microbial isolates with different characteristics were purified and tested for their abilities to inhibit $A$. solani in vitro using a dual culture method (Dhingra and Sinclair, 1995).

The isolates that showed more than $50 \%$ inhibition were tested again for confirmation and statistical analysis. The experiment was arranged in completely randomized design with ten treatments and three replications. The treatments comprised nine selected microbial isolates and the check (the pathogen was cultured without the antagonistic microbes). The radial growth of the pathogen toward the tested microbes was observed every day for up to seven days incubation.

Statistical analysis: The data were statistically analysed using analysis of varians (ANOVA) by means of the SPSS version 20. The data were checked for normality and transformed if necessary. Treatments with significant differences were further analysed using Tukey's Honest Significant Difference (HSD).

\section{RESULTS}

Powdery mildew disease: The application of compost and compost plus inhibited the development of powdery mildew disease on the greenhouse tomatoes. In the check, the disease symptom started to appear four days after inoculation, while in the treatment of compost or compost plus, the symptoms appeared five to seven days after inoculation. The AUDPC value reflected the total development of the disease during the observation. In general, the AUDPC values in tomatoes treated with enriched compost were significantly smaller $(P<0.05)$ than that of non-enriched compost, fungicide, and also the untreated plants (Table 1). The enriched compost showed better disease suppressive effects than nonenriched compost. The combination of the application of compost (enriched or non-enriched) in the growth medium and foliar sprays of their water extract showed relatively better suppression of powdery mildew disease than only spraying the water extract onto the leaves. The best disease suppression (48.5\%) was observed in the treatment of compost plus, applied at the planting holes and its water extract was sprayed onto the leaves every three days, after the onset of early blight disease.

The applications of compost and compost plus improved the tomato growth. The plant height and shoot fresh weight of tomatoes, treated with compost or compost plus, were significantly higher $(P<0.05)$ than the untreated plants, and the fungicide treatment. The incorporation of compost plus in the growth media and spraying its water extract (every three or seven days) tended to result in relatively better shoot dry weight than with other treatments (Table 2).

Early blight disease: The resulting trend of this field experiment was similar to that of the greenhouse experiment. The application of microbial-enriched compost tended to provide better suppression of early blight disease (by 37.7-47.5\%) than non-enriched compost (24.3-30.3\%) (Table 3). The combination of the applications (incorporation in the growth medium and regular foliar sprays) tended to result in higher disease suppression than foliar sprays of the water extract merely.

In this field experiment, the highest disease suppression $(70 \%)$ was found in the fungicide treatment. The applications of compost plus in the nursery medium and planting hole, combined with foliar applications of its water extract every three or seven days, suppressed the disease by $47.5 \%$ and $41.9 \%$, respectively (Table 3 ).

In this experiment, early blight infection was also observed on the tomato fruits. The infection usually started from the petiole, therefore, the infected fruits dropped off easily. The weight of healthy tomatoes in most treatments with compost or compost plus were not significantly different to that of the untreated plants. The treatment that showed significant increase in the weight of healthy tomato fruits was the incorporation of compost plus into the growth medium and spraying its water extract every three days. The weight of healthy fruits in that treatment was not significantly different to that of the fungicide treatment (Table 3).

In vitro effects: The non-sterile water extracts of compost and compost plus inhibited the growth of $A$. solani by $71.8 \%$ and $82.1 \%$, respectively. The sterilisation of the water extracts, however, reduced their inhibitory effects. The sterile water extract of compost plus showed quite low inhibition effects on the pathogen $(20.5 \%)$, whereas the sterile water extract of compost did not inhibit the growth of the pathogen (Table 4).

The non-sterile water extracts contained bacterial and fungal isolates, in which some of them inhibited the growth of $A$. solani. The population of 
bacteria in the water extract of compost or compost plus was higher $\left(10^{6-7} \mathrm{cfu} \mathrm{mL} \mathrm{m}^{-1}\right)$ than the fungi $\left(10^{3-4} \mathrm{cfu} \mathrm{mL}^{-}\right.$ $\left.{ }^{1}\right)$. The fungal genera found in the water extract of compost plus were Trichoderma, Papulaspora and Aspergillus (brown isolate), whilst the fungi found in the water extract of compost were Trichoderma, Aspergillus (green, brown and black isolates), and Penicillium. The fungal isolates, Trichoderma and Papulaspora found in the water extract of compost plus were similar to the isolates used for enrichment of the compost. The population of Trichoderma in the water extract of compost plus was higher $\left(1.5 \times 10^{4} \mathrm{cfu} \mathrm{mL}^{-1}\right)$ than in the compost water extract $\left(0.5 \times 10^{3} \mathrm{cfu} \mathrm{mL}^{-1}\right)$. The population of Papulaspora was $1.3 \times 10^{3} \mathrm{cfu} \mathrm{mL}^{-1}$.
The results of the dual culture test showed that among 19 microbial isolates found in the water extracts, nine isolates inhibited the growth of $A$. solani in vitro by more than $50 \%$. Most of the antagonistic isolates were obtained from compost plus water extract. In further dual culture test, all selected isolates inhibited the pathogen growth by $55.9-83.5 \%$. The highest inhibition level was showed by a bacterial isolate, from water extract of compost plus, CPWE1. The fungal isolates, similar to the ones added to the compost plus, T. harzianum and Papulaspora sp. inhibited the pathogen by $77.5 \%$ and $66.9 \%$ respectively (Table 5).

Table 1. The effects of compost and compost plus on powdery mildew disease in greenhouse tomatoes.

\begin{tabular}{|c|c|c|c|}
\hline Treatments & $\begin{array}{c}\text { Incubation } \\
\text { period } \\
\text { (days) }\end{array}$ & $\begin{array}{c}\text { AUDPC } \\
\text { value }\end{array}$ & $\begin{array}{c}\text { Disease } \\
\text { inhibition } \\
(\%)\end{array}$ \\
\hline A: Compost plus in growth media + its water extract was sprayed every three days & 7 & $661.9^{\mathrm{a}}$ & 48.5 \\
\hline B: Compost plus in growth media + its water extract sprayed every seven days & 7 & $722.5^{\mathrm{ab}}$ & 43.8 \\
\hline C: Compost in growth media + its water extract sprayed every three days & 6 & $1024.3^{\mathrm{cd}}$ & 20.3 \\
\hline D: Compost in growth media + its water extract sprayed every seven days & 6 & $995.0^{\mathrm{cd}}$ & 22.6 \\
\hline E: Compost plus water extract sprayed every three days & 6 & $778.8^{\mathrm{abc}}$ & 39.4 \\
\hline F. Compost plus water extract sprayed every seven days & 5 & $971.4^{\mathrm{bcd}}$ & 24.4 \\
\hline G. Compost water extract sprayed every three days & 5 & $1067.8^{\mathrm{de}}$ & 16.9 \\
\hline H. Compost water extract sprayed every seven days & 5 & $1051.7^{\mathrm{de}}$ & 18.1 \\
\hline I: Fungicide (propineb) & 5 & $1114.3^{\mathrm{de}}$ & 13.3 \\
\hline $\mathrm{J}$ : Check & 4 & $1284.9^{\mathrm{e}}$ & 0.0 \\
\hline
\end{tabular}

Note: the same notation in the same columns are not significantly different, based on Tukey's HSD $(P<0.05)$

Table 2. The effect of compost and compost plus on the growth of tomato plants.

\begin{tabular}{lcc}
\hline \multicolumn{1}{c}{ Treatments } & $\begin{array}{c}\text { Average of Plant } \\
\text { height (cm) }\end{array}$ & $\begin{array}{c}\text { Average of shoot } \\
\text { fresh weight }\end{array}$ \\
\hline A : Compost plus in growth media + its water extract sprayed every three days & $118.5^{\mathrm{b}}$ & $162.5^{\mathrm{d}}$ \\
B: Compost plus in growth media + its water extract sprayed every seven days & $117.3^{\mathrm{b}}$ & $158.7^{\mathrm{d}}$ \\
C : Compost in growth media + its water extract sprayed every three days & $116.8^{\mathrm{b}}$ & $156.2^{\mathrm{cd}}$ \\
D: Compost growth media + its water extract sprayed every seven days & $115.3^{\mathrm{b}}$ & $150.3^{\mathrm{cd}}$ \\
E: Compost plus water extract sprayed every three days & $115.0^{\mathrm{b}}$ & $153.3^{\mathrm{cd}}$ \\
F. Compost plus water extract sprayed every seven days & $114.8^{\mathrm{b}}$ & $149.5^{\mathrm{cd}}$ \\
G. Compost water extract sprayed every three days & $112.8^{\mathrm{b}}$ & $144.1^{\mathrm{bcd}}$ \\
H. Compost water extract sprayed every seven days & $111.5^{\mathrm{b}}$ & $138.0^{\mathrm{bc}}$ \\
I : Fungicide (propineb) & $97.5^{\mathrm{a}}$ & $101.8^{\mathrm{a}}$ \\
J: Check & $10.2^{\mathrm{a}}$ & $123.7^{\mathrm{ab}}$ \\
\hline
\end{tabular}

Note: the same notation in the same columns are not significantly different, based on Tukey's HSD $(P<0.05)$

Table 3. The effect of compost and antagonist-enriched compost on early blight disease in field-grown tomato plants.

\begin{tabular}{lccc}
\hline \multicolumn{1}{c}{ Treatments } & AUDPC & $\begin{array}{c}\text { Disease } \\
\text { Inhibition } \\
(\%)\end{array}$ & $\begin{array}{c}\text { Healthy } \\
\text { Fruit weight } \\
\text { per plant (g) }\end{array}$ \\
\hline A : Compost plus in growth media + its water extract sprayed every three days & $765.9^{\mathrm{b}}$ & 47.5 & $1062.7^{\mathrm{cd}}$ \\
B: Compost plus in growth media + its water extract sprayed every seven days & $848.7^{\text {bc }}$ & 41.9 & $950,0^{\text {abc }}$ \\
C: Compost in growth media + its water extract sprayed every three days & $1017.0^{\text {de }}$ & 30.3 & $818.6^{\mathrm{a}}$
\end{tabular}


D: Compost growth media + its water extract sprayed every seven days

E: Compost plus water extract sprayed every three days

F. Compost plus water extract sprayed every seven days

G. Compost water extract sprayed every three days

H. Compost water extract sprayed every seven days

I : Fungicide (mancozeb)

J: Check

$\begin{array}{lcc}1035.5^{\mathrm{e}} & 29.1 & 956.7^{\mathrm{abc}} \\ 890.0^{\mathrm{bc}} & 39.0 & 889.7^{\mathrm{a}} \\ 908.9^{\mathrm{cd}} & 37.7 & 842.0^{\mathrm{a}} \\ 1060.2^{\mathrm{e}} & 27.4 & 953.7^{\mathrm{abc}} \\ 1104.8^{\mathrm{e}} & 24.3 & 940.0^{\mathrm{abc}} \\ 425.1^{\mathrm{a}} & 70.3 & 1127.0^{\mathrm{d}} \\ 1460.4^{\mathrm{f}} & 0.0 & 911.0^{\mathrm{ab}}\end{array}$

Note: the same notation in the same columns are not significantly different, based on Tukey's HSD $(P<0.05)$

Table 4. The effects of water extract of compost or compost plus on $A$. solani in vitro.

\begin{tabular}{lcc}
\hline \multicolumn{1}{c}{ Treatments } & Radial growth of fungus (cm) & Level of inhibition (\%) \\
\hline Sterile water extract of compost plus & $3.1^{\mathrm{b}}$ & 20.5 \\
Sterile water extract of compost & $3.6^{\mathrm{bc}}$ & 7.7 \\
Non sterile water extract of compost plus & $0.7^{\mathrm{a}}$ & 82.1 \\
Non sterile water extract of compost & $1.1^{\mathrm{a}}$ & 71.8 \\
Check & $3.9^{\mathrm{c}}$ & 0.0 \\
\hline
\end{tabular}

Note: the same notations in the same columns are not significantly different, based on Tukey's HSD $(P<0.05)$

Table 5. The antagonistic effects of microbes isolated from water extract of compost and compost plus on the fungal pathogen, A. solani.

\begin{tabular}{llcc}
\hline Microbial Isolates & The sources of Isolates & $\begin{array}{c}\text { Radial growth of the } \\
\text { pathogen towards the } \\
\text { tested fungus }(\mathbf{c m})\end{array}$ & $\begin{array}{c}\text { Inhibition } \\
\mathbf{( \% )}\end{array}$ \\
\hline T. harzianum & Compost plus water extract & $0.8^{\mathrm{ab}}$ & 77.5 \\
Papulaspora sp. & Compost plus water extract & $1.2^{\mathrm{bc}}$ & 66.9 \\
Aspergillus sp. (brown) & Compost plus water extract & $1.5^{\mathrm{c}}$ & 58.7 \\
Aspergillus sp. (green) & Compost water extract & $0.9^{\mathrm{ab}}$ & 74.3 \\
Aspergillus sp. (black) & Compost water extract & $1.2^{\mathrm{bc}}$ & 66.9 \\
Penicillium sp. & Compost water extract & $1.1^{\mathrm{bc}}$ & 68.8 \\
Bacterial isolate CPWE1 & Compost plus water extract & $0.6^{\mathrm{a}}$ & 83.5 \\
Bacterial isolate CPWE2 & Compost plus water extract & $1.1^{\text {bc }^{\mathrm{b}}}$ & 68.8 \\
Bacterial isolate CWE1 & Compost water extract & $1.6^{\mathrm{c}}$ & 55.9 \\
Check & & $3.6^{\mathrm{d}}$ & 0.0 \\
\hline
\end{tabular}

Note: the same notation in the same columns are not significantly different, based on Tukey's HSD $(P<0.05)$

\section{DISCUSSION}

The compost water extract or non-aerated compost tea has been reported to effectively control aerial diseases in tomatoes, such as powdery mildew by $45-$ $62 \%$, and grey mould (Botrytis cinerea) by $97 \%$ (Koné et al., 2010), or to have curative effect on powdery mildew (Erysiphe polygoni) by up to $100 \%$ (Segarra et al., 2009). However, in this study compost water extract was not effective in controlling powdery mildew and early blight diseases in tomatoes. The water extract of compost only reduced the disease intensity of powdery mildew by $16.9-18.1 \%$ and early blight in tomatoes by $24.3-27.4 \%$. The differences in the efficacy of the compost water extract may be related to the difference in the raw materials of the compost, which lead to differences in the diversity and abundance of microbes that are antagonistic to the pathogens. It has been reported that different kinds of raw materials of composts led to the differences in their efficacies (Koné et al., 2010; Sang et al., 2010). Deepthi and Reddy (2013) found that the microbiota in the compost tea was influenced by the composition of the compost materials and the microbial enrichment of the compost.

The augmentation of the antagonistic fungi in the compost increased the suppressive effect on powdery mildew and early blight diseases in tomatoes. Even though the compost was enriched with rhizosphere fungi (T. harzianum, Papulaspora sp., and P. fumosoroseus), its water extract showed suppressive effects on airborne diseases. In vitro assessment showed that the added fungi, T. harzianum sp. and Papulaspora sp., were found in the water extract of compost plus. The existence of these antagonistic fungi in the water extract seemed to enhance the disease suppressive effect. In the in vitro experiment, T. harzianum and Papulaspora sp. inhibited the growth of A. solani. The ability of Trichoderma sp. to control airborne disease was also reported in other studies 
(Sawant, 2014). The addition of $T$. harzianum in the water extract of rice straw compost also enhanced its suppressive effect on wet rot of okra (Siddiqui et al., 2008).

The mechanisms of the water extract of compost or compost plus in suppressing the disease were mainly due to the existence of microorganisms in the extract, rather than the toxic compounds in the extract. The nonsterile water extracts of compost or compost plus was effective in inhibiting the pathogen growth, whilst the filter-sterilised extract was not effective. The water extract of compost or compost plus contained bacteria and fungi, which were antagonistic to $A$. solani. This result is in line with other studies on compost teas, in which generally, their suppressive effects were mainly due to microbial activities (Koné et al., 2010; Deepthi and Reddy, 2013).

The results of this study also showed that combining the application of microbial-enriched compost into the growth media (in the nursery and planting site) and spraying its water extract onto the leaves enhanced the disease suppressive effects. This result is in line with the results found by Istifadah and Nasahi (2007), in which combination of the application of compost or vermicompost in the planting site and spraying their water extract onto the leaves, resulted in a higher suppressive effect than solely application in either ways.

The application of compost plus in the growth media may also enhance the plant's resistance to the disease. Istifadah and Hakim (2017) reported that the application of compost plus in the planting media reduced early blight disease in tomato leaves, indicating the increase of plant resistance. The abilities of compost to enhance plant resistance have also been reported. The application of organic matter, including compost in the planting site, reduced airborne diseases (Yogev et al., 2010; Istifadah and Hakim, 2017), probably through enhancing plant resistance, as a result of the increase in nutrients and/or activation of plant defence genes (systemic induced resistance) (Yogev et al., 2010). The addition of $T$. harzianum in compost plus seems to enhance the induction of resistance, as the fungus itself may also induce plant resistance to the disease. Istifadah and Hakim (2017) found that application of T. harzianum in planting media improved tomato resistance to early blight disease. Vitti et al. (2016) also reported that $T$. harzianum was able to induce tomato resistance to cucumber mozaic virus.

In addition to the disease suppressive effects, the application of compost and compost plus also enhanced the growth and yield of tomatoes. As organic fertiliser, compost and compost water extract contains nutrients that supports plant growth (Marín et al., 2013; Hargreaves et al., 2014). The enrichment of compost with T. harzianum, Papulaspora sp., and P. fumosoroseus tended to result in better effects on tomato growth and yield. Trichoderma sp. is known as a plant growth promoting fungus (Saba et al., 2012), therefore, it may improve the effect of compost plus in supporting plant growth. In addition to the direct effect of the compost and compost plus, the improvement of tomato growth and yield was also due to the suppression of the disease.

Conclusions: The overall results showed that the enrichment of compost with soil antagonistic microbes can improve the disease suppressive effects of its water extract to foliar diseases. The efficacy of the water extract to control airborne diseases can also be enhanced by the incorporation of the enriched compost into the growth medium. With this combination, compost plus can be used to control soilborne and airborne diseases simultaneously. This eco-friendly control measure can be a part of integrated pest management in sustainable agriculture, particularly in organic farming.

Acknowledgement: We would like to thank Universitas Padjadjaran, Bandung, Indonesia for the financial support of this study.

\section{REFERENCES}

Campbell, L.C and V.L. Madden (1990). Introduction plant disease epidemiology. John Wiley and Son, USA. 532 pp.

Cerkauskas, R.F., and J. Brown (2015). Aspects of the epidemiology and control of powdery mildew (Oidium neolycopersici) on tomato in Ontario, Canada. Can. J. Plant. Pathol. 37:448-464

Deepthi, K.P. and P.N. Reddy (2013). Compost Teas: A potential source of antagonistic microflora against plant diseases. J. Cell Life Sci. 1 (1): 619

Dhingra, O.D. and J.B. Sinclair (1995). Basic plant pathology methods. Second edition. Lewis Publishers, Boca Raton. 434 pp.

Gulzar N., A.N. Kamili, and M.Y. Mir (2018). The process of early blight disease development in tomato. J. Res. Dev. 18: 112-115.

Hargreaves, J.C., M.S. Adla, and P.R. Warman (2014). Are compost teas an effective nutrient amendment in the cultivation of strawberries? Soil and plant tissue effects. J. Sci. Food Agric. 89: 390-397.

Istifadah, N. and C. Nasahi, 2007. The use of compost and vermi-compost to suppress rust disease (Phakopsora pachyrrizi Syd) in soybean. J. Agrikultura. 18 (1): 42-47 (Indonesian with Abstract in English).

Istifadah, N. and N. Hakim, 2017. The abilities of compost and compost plus to enhance tomato resistance to early blight disease (Alternaria solani Sor.). J. Agrikultura 28 (3): 111-117 (Indonesian with Abstract in English). 
Istifadah, N., T. Sunarto, D.E. Kartiwa, and D. Herdiyantoro (2008). The ability of compost plus in suppressing fusarial wilt disease (Fusarium oxysporum f.sp. lycopersici) in tomato. J. Agrikultura 19 (1): 60-65 (Indonesian with Abstract in English).

Jacob, D., D.R. David, A. Sztjenberg, and Y. Elad. (2008). Conditions for development of powdery mildew of tomato caused by Oidium neolycopersici. Phytopathology 98:270-281.

Koné, S.B, A. Dionne, R.J. Tweddell, H. Antoun, and T.J. Avis (2010). Suppressive effect of nonaerated compost teas on foliar fungal pathogens of tomato. Biol. Control 52 (2): 167-173.

Mahmood, I., S.R. Imadi, K. Shazadi, A. Gul, and K.R. Hakeem (2016). Effects of Pesticides on Environment In: Hakeem, K. R., M.S. Akhtar, S.N.A. Abdullah (Eds.), Plant, soil and microbes, volume 1: Implications in crop science. Springer International, Switzerland, pp: 254-269

Marín, F., M. Santos, F. Diánez, F. Carretero, F.J. Gea, J.A. Yau, and M.J. Navarro (2013). Characters of compost teas from different sources and their suppressive effect on fungal phytopathogens. World J. Microbiol. Biotechnol, 29(8): 13711382.

Mehta C.M., U. Palni, I.H. Franke-Whittle, and A.K. Sharma (2014) Compost: its role, mechanism and impact on reducing soil-borne plant diseases. Waste Manag. 34(3): 607-622.

Pugliese, M., B. Liu, M.L. Gullino, and A. Garibaldi (2011). Microbial enrichment of compost with biological control agents to enhance suppressiveness to four soil-borne diseases in greenhouse. J. Plant Dis. Prot. 118 (2): 45-50.

Ros M, I. Raut, A.B. Santisima-Trinidad, and J.A. Pascual (2017) Relationship of microbial communities and suppressiveness of Trichoderma fortified composts for pepper seedlings infected by Phytophthora nicotianae. PLoS ONE 12 (3): e0174069, doi: 10.1371/journal.pone.0174069.
Saba H., D. Vibhash, M. Manisha, K.S. Prashant, H. Farhan, and A. Tauseef (2012). Trichoderma a promising plant growth stimulator and biocontrol agent. Mycosphere 3 (4): 524-531.

Sang M.K. and K.D. Kim (2011). Biocontrol activity and primed systemic resistance by compost water extract against antrachnose of pepper and cucumber. Phytopathology 101: 732-740.

Sang, M.K., J.G. Kim, and K.D. Kim (2010). Biocontrol activity and induction of systemic resistance in pepper by compost water extracts against Phytophthora capsici. Phytopathology 100: 774 783.

Sawant, I.S. (2014). Trichoderma-foliar pathogen interactions. Open Mycol J., 8 (Suppl-1, M3): 58-70.

Segarra G., G. Santpere, G. Elena, and M.I. Trillas (2013) Enhanced Botrytis cinerea resistance of arabidopsis plants grown in compost may be explained by increased expression of defenserelated genes, as revealed by microarray analysis. PLoS ONE 8(2): e56075. doi:10.1371/journal.pone.0056075.

Segarra, G., M. Reis, E. Casanova, and M.I. Trillas (2009). Control of powdery mildew (Erysiphe polygoni) in tomato by foliar applications of compost tea. J. Plant Pathol. 91 (3): 683-689.

Siddiqui, Y., S. Meon, M.R. Ismail, and A. Ali (2008). Trichoderma-fortified compost extracts for the control of Choanephora wet rot in okra production. Crop Prot. 27: 385-390.

St. Martin, C.C.G. (2014). Potential of compost tea for suppressing plant diseases. CAB Reviews 9 (032): 1-38.

Vitti A., E. Pellegrini, C. Nali, S. Lovelli, A. Sofo, M. Valerio, A. Scopa, and M. Nuzzaci (2016) Trichoderma harzianum T-22 induces systemic resistance in tomato infected by Cucumber mosaic virus. Front. Plant Sci. 7:1520. doi: 10.3389/fpls.2016.01520.

Yogev, A., M. Raviv, Y. hadar, R. Cohen, S. Wolf, L. Gill and J. Katan (2010) Induced resistance as a putative component of compost suppressiveness, Biol. Control. 54: 46-51. 